\title{
EDWIN CLARKE AT THE WELLCOME INSTITUTE
}

On 31 December 1979 Edwin Clarke, M.D., F.R.C.P., relinquished his post as Director of the Wellcome Institute for the History of Medicine in order to devote himself full time to his investigations into the history of the neuro-medical sciences. Readers of this journal will be familiar with his earlier work in the subject, including (with C. D. O'Malley) The human brain and spinal cord (University of California Press, 1968), and (with Kenneth Dewhurst) An illustrated history of brain function (Sandford Publications, 1972). More recently, he has completed a translation and revision of Max Neuburger's classic Die historische Entwicklung der experimentellen Gehirn- und Rückenmarks-physiologie vor Flourens which will be published shortly by the Johns Hopkins University Press.

Edwin Clarke became Director of the Wellcome Institute on 1 October 1973, having since 1966 been Head of the Sub-Department of the History of Medicine, established by the Wellcome Trust at University College, London. While there, he developed a teaching programme in the history of medicine which at the time was unique in Britain. The Wellcome Trustees were interested in the furtherance of the history of medicine as an academic discipline, and when Dr. Clarke became Director of the Institute he was charged with the responsibility of forging closer formal ties between the Institute and University College. After long negotiations between the Wellcome Trust, the Institute, and College, the Institute's Academic Unit was established in January 1977. Members of the Academic Unit hold joint appointments at both Institute and College and offer undergraduate and postgraduate courses to medical, science, and arts students from many colleges and medical schools of the University of London. One particularly important feature of this programme is the opportunity given to third-year pre-clinical medical students to spend a full year studying the history of medicine for the B.Sc. degree from London University. Together with the academic staff of the Library, the six members of the Unit constitute the largest group of professional medical historians in the world.

The creation of the Academic Unit was complicated by taking place at the same time as the transfer of the Wellcome Collection of medical artefacts on permanent loan to the Science Museum, South Kensington. It was Dr. Clarke who, above all, was responsible for seeing that the move took place as smoothly as possible and for ensuring a harmonious relationship between Institute and Museum personnel. The Collection will go on public display at the Science Museum at the end of 1980 . A small collection, retained at the Institute, will be used to develop a course on the history of medical technology.

More recently the Institute's activities have been widened by the creation in 1978 of the Contemporary Medical Archives Centre. Its staff are developing a collection of primary sources reflecting all aspects of modern medicine, from the research which leads to major scientific advances, to clinical practice, public health, unorthodox and fringe medicine. 


\section{Editorial}

Dr. Clarke also devoted considerable time to the editing of Medical History. His successors as editors intend to maintain the high standards of scholarship that he has taught them, and look forward in their turn to publishing some of the fruits of his present researches.

W. Bynum

V. Nutton

\section{THEORIES OF FEVER, ANTIQUITY TO EARLY NINETEENTH CENTURY}

A one-day conference on the history of fever will be held at the Wellcome Institute for the History of Medicine on Friday, 13 June 1980, sponsored by the Wellcome Trust. Registration fee of $£ 3.50$ includes coffee, lunch, tea, and a set of pre-circulated papers. Details from Dr. W. F. Bynum, Wellcome Institute for the History of Medicine, 183 Euston Road, London NW1 2BP.

\section{HISTORICAL ASPECTS OF NEUROLOGY}

A conference on historical aspects of neurology will be held on Wednesday 23 and Thursday 24 July 1980 at the Medical Society of London, in honour of the eightieth birthday of Dr. Macdonald Critchley. It is sponsored by the World Federation of Neurology and the Wellcome Institute for the History of Medicine, and will include papers on many aspects of the history of clinical neurology and neuro-biology. Details available from Dr. W. F. Bynum, Wellcome Institute for the History of Medicine, 183 Euston Road, London NW1 2BP.

\section{DR. E. ASHWORTH UNDERWOOD}

We regret to record the death on 6 March 1980 of Dr. E. Ashworth Underwood, M.A., M.D., D. Litt., D.P.H., F.R.C.P., F.L.S. Dr. Underwood was Director of the Wellcome Historical Medical Museum from 1946 to 1964. An obituary will be published in the July 1980 issue of Medical History. 